\title{
Age and growth of the deep water mud shrimp Solenocera melantho (De Man, 1907) off Visakhapatnam coast, India
}

\author{
P. R. C. GANESH AND MYLA. S. CHAKRAVARTY \\ Department of Marine Living Resources, Andhra University, Visakhapatnam - 530 003, Andhra Pradesh, India \\ e-mail: mylaschakravarty@gmail.com
}

\begin{abstract}
Age and growth of the deep water mud shrimp Solenocera melantho (De Man, 1907) was estimated using von Bertalanffy growth model employing modal progression analysis, Ford-Walford method for $\mathrm{L}_{\infty}$ and $\mathrm{K}$ and $\mathrm{t}_{0}$ by Gulland's method as well as ELEFAN I (FiSAT II software version 1.2.2) method. The growth parameters estimated by the former method were: $\mathrm{L}_{\infty}=107.9 \mathrm{~mm}, \mathrm{~K}=2.61 \mathrm{y}^{-1}, \mathrm{t}_{0}=0.1344, \varphi^{\prime}=4.4825$ for males and $\mathrm{L}_{\infty}=116.4 \mathrm{~mm}, \mathrm{~K}=3.69 \mathrm{y}^{-1}, \mathrm{t}_{0}=0.1346, \varphi^{\prime}=4.6997$ for females and by the latter method were $: \mathrm{L}_{\infty}=106.1 \mathrm{~mm}, \mathrm{~K}=2.17 \mathrm{y}^{-1}, \mathrm{t}_{0}=-0.05, \varphi^{\prime}=4.3879$ for males and $\mathrm{L}_{\infty}=116.8 \mathrm{~mm}$, $\mathrm{K}=2.1 \mathrm{y}^{-1}, \mathrm{t}_{0}=-0.05, \varphi^{\prime}=4.4571$ for females. The longevity estimated for both males and females of $S$. melantho was about 36 months. The females were observed to grow faster than the males.
\end{abstract}

Keywords: Age, Deep water mud shrimp, Growth, Solenocera melantho

\section{Introduction}

Shrimps have a short life span. They may have one or two identifiable characteristics in a sample and their data have to originate from samples caught at different times (Pauly, 1983). A common approach is to analyse length frequency data to a mixture of finite number of normal distributions, each of which corresponds to a different age class (Niamaimandi et al., 2007). According to Yano and Kobayashi (1969), assessment of growth parameters and age is difficult in shrimps, since they do not have bony structures. Though there is an increase in the number of lamellae in the endocuticle with size, periodic moulting and discontinuous growth makes tagging experiments unreliable (Rao and Krishnamurthy, 1990). The use of a polymodal length-frequency curve analysis to distinguish and separate age groups from modes in the curves is difficult because shrimps have a protracted breeding season (Rao and Krishnamurthy, 1990). Growth parameters differ between species, but they may also vary from stock to stock within the same species (Sparre and Venema, 1992).

According to Garcia and Le Reste (1981), the best estimate of growth in shrimps is by tag-recapture. Electronic Length-Frequency Analysis (ELEFAN) is the most commonly used computer programme for shrimp growth (Pauly and David, 1981). Hall (1962) reported the growth rate from frequency histograms of carapace length and total length of selected shrimps of Indo-West Pacific. The age and growth of Solenocera crassicornis of Bombay waters was studied by Sukumaran (1978) and that of Solenocera membranacea from the central Adriatic Sea by Froglia and Gramitto (1987). Demestre and Abello (1993) made investigations on the growth of $S$. membranacea in the North-western Mediterranean Sea. Baelde (1994) applied the MULTIFAN method to analyse the age composition, growth, mortality and yield-per-recruit in deep water royal red shrimp Haliporoides sibogae off Eastern Australia. Ohtomi and Irieda (1997) described the growth of the deepwater mud shrimp Solenocera melantho (De Man, 1907) using length-frequency analysis in Kagoshima Bay. Oh et al. (2005) studied the growth of $S$. melantho around Geomun Island, Korea. Dineshbabu and Joseph (2007) determined the age and growth of $S$. choprai using length-frequency analysis and Li et al. (2012) reported the growth of $S$. melantho from the East China Sea.

According to Maheswarudu et al. (2014; 2015), 24 species of penaeid shrimps contribute on an average $13.7 \%$ to the total fish landings of Visakhapatnam and the share of $S$. melantho was $7.2 \%$. It is commercially important in local markets as a source of protein. Since there is no information on age and growth of the species in Indian waters, an attempt is made in the present study to estimate age and growth of $S$. melantho off Visakhapatnam coast.

\section{Materials and methods}

Specimens of $S$. melantho were collected fortnightly from the trawl catches at Visakhapatnam Fishing Harbour for two years i.e., from November, 2004 to October, 
2006 except during fishing holiday in May. The specimens were segregated into males and females and their total length was measured $( \pm 1 \mathrm{~mm})$. For growth studies, 1485 males (60-101 mm) and 1614 females (54-114 mm) were examined. They were grouped into $3 \mathrm{~mm}$ class intervals and the data collected twice in a month were pooled. Length-frequency distribution was analysed for males and females separately. The age and growth of the males and females were studied using von Bertalanffy growth equation (1938).

$\mathrm{L}_{\mathrm{t}}=\mathrm{L}_{\infty}\left(1-\mathrm{e}^{-\mathrm{K}(\mathrm{t}-\mathrm{to})}\right)$

where, $\mathrm{L}_{\mathrm{t}}$ is the length at age, $\mathrm{t} ; \mathrm{L}_{\infty}$ is the average asymptotic length to which the individual grows; $\mathrm{K}$ is the growth coefficient and $t_{0}$ is the theoretical age of the individual at zero size.

Parameters for the growth equation were estimated by: a) tracing of modal progression by lengthfrequency analysis and following their progression over ages (Rao and Krishnamoorthi, 1990; Maheswarudu et al., 1994); estimation of $\mathrm{L}_{\infty}$ and $\mathrm{K}$ by Ford (1933)-Walford method (1946) and estimation of $t_{0}$ by Gulland's method (1969). b) The month-wise length frequency data was also analysed by ELEFAN I (Pauly and David, 1981) (FiSAT II Software package, version 1.2.2) module to get the estimate of $\mathrm{L}_{\infty}$ and $\mathrm{K}$. Using these values, $\mathrm{t}_{\mathrm{o}}$ was calculated by Pauly's equation (Pauly, 1979):

$\log \left(-\mathrm{t}_{\mathrm{o}}\right)=-0.392-0.275 \log \left(\mathrm{L}_{\infty}\right)-1.038 \log \mathrm{K}$.

The values of $\mathrm{L}_{\infty}, \mathrm{K}$ and $\mathrm{t}_{0}$ thus obtained were fitted in the von Bertalanffy growth equation.

Growth performance index ( $\left.\varphi^{\prime}\right)$ (Pauly and Munro, 1984)

The growth performance index $\left(\varphi^{\prime}\right)$ was estimated using the formula:

$\varphi^{\prime}=\log \mathrm{K}+2 \log \mathrm{L}_{\infty}$

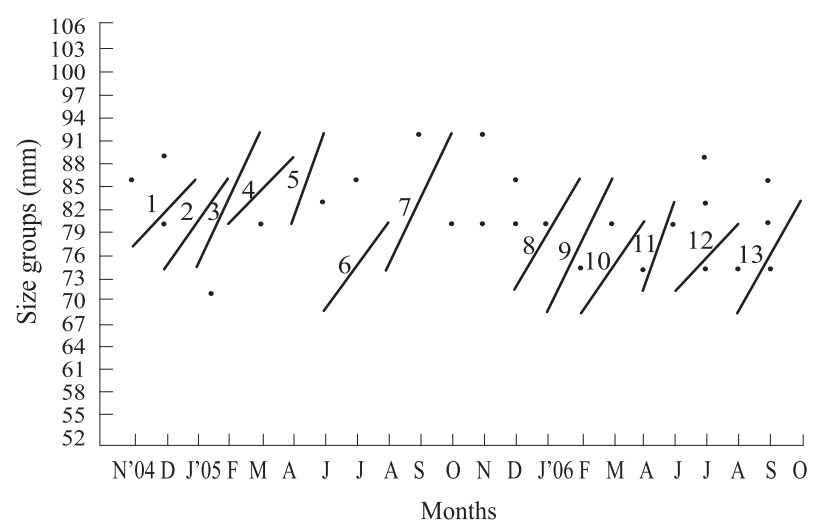

(a) where, $\mathrm{K}=$ growth constant per year and $\mathrm{L}_{\infty}=$ asymptotic length

Growth rate (Ohtomi and Iredia, 1997)

The monthly growth rate (MGR) was calculated using the equation:

$\operatorname{MGR}(\%)=100 \times \frac{\left(L_{t+1}-L_{t}\right)}{L_{t}}$

where, $\mathrm{L}_{\mathrm{t}}$ and $\mathrm{L}_{\mathrm{t}+1}=$ lengths at age $\mathrm{t}$ and $\mathrm{t}+1$ (months)

The value of growth constant obtained was for two months as the time interval between $\mathrm{L}_{\mathrm{t}}$ and $\mathrm{L}_{\mathrm{t}+1}$ was two months.

\section{Results and discussion}

Length-frequency analysis

The modes traceable up to two months were taken into consideration since the modes lost their identity afterwards in the length-frequency distribution. A total of 13 modes for males and 15 for females were traced as scatter diagrams (Fig. 1 a, b). The modes of the modalchains were used to estimate the growth parameters $\mathrm{L}_{\infty}$ and $\mathrm{K}$.

Asymptotic length $\left(L_{\infty}\right)$ and growth coefficient $(K)$

Modes traceable for two months were plotted by Walford method (1946). Initial mode was $\mathrm{L}_{\mathrm{t}}$ and the final mode $\mathrm{L}_{\mathrm{t}+1}$. Growth constant $(\mathrm{K})$ was calculated for males and females from the graphical representation (Fig. $2 \mathrm{a}, \mathrm{b}$ ) of $\mathrm{L}_{\mathrm{t}+1}$ and $\mathrm{L}_{\mathrm{t}}$. Values of $\mathrm{L}_{\infty}$ for males and females were found to be in close agreement with the maximum length recorded $\left(\mathrm{L}_{\max }\right)$ for males $(101 \mathrm{~mm})$ and females $(114 \mathrm{~mm}) . \mathrm{L}_{\infty}$ for males and females were 107.88 and $116.39 \mathrm{~mm}$ respectively. Bimonthly growth coefficient for males was 0.43 and for females 0.61 whereas the annual values were 2.61 and 3.69 respectively.

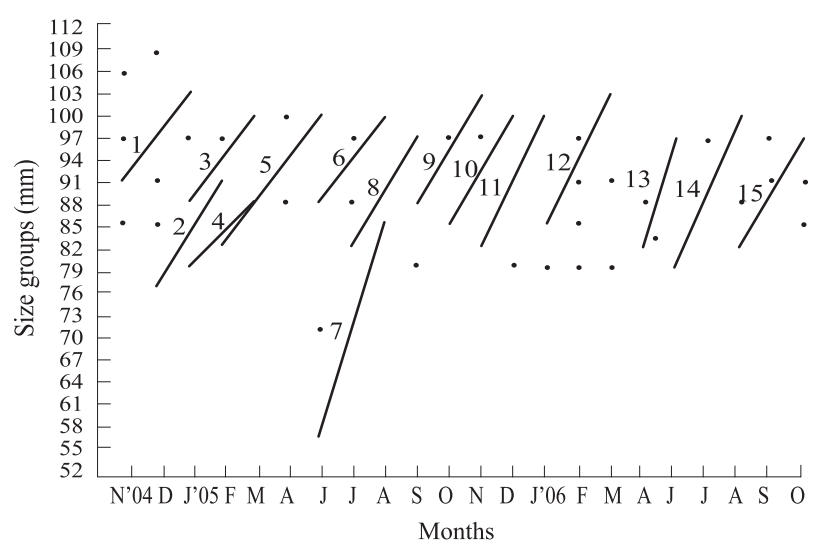

(b)

Fig. 1. Scatter diagram of modal values and mode-chains of different size groups in S. melantho. (a): Male, (b): Female 


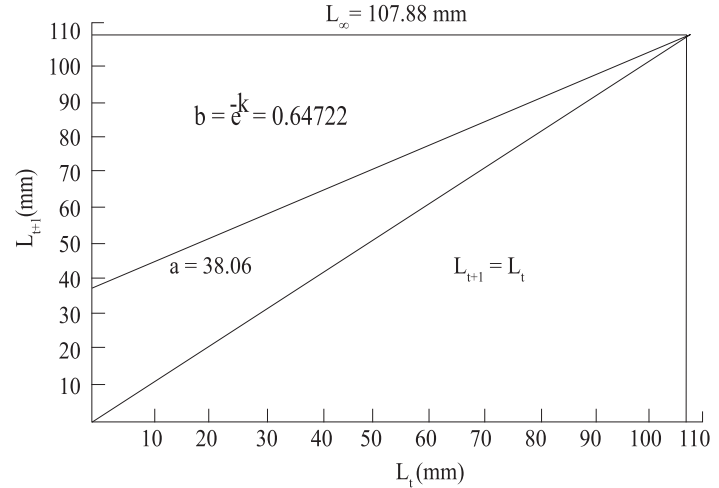

(a)

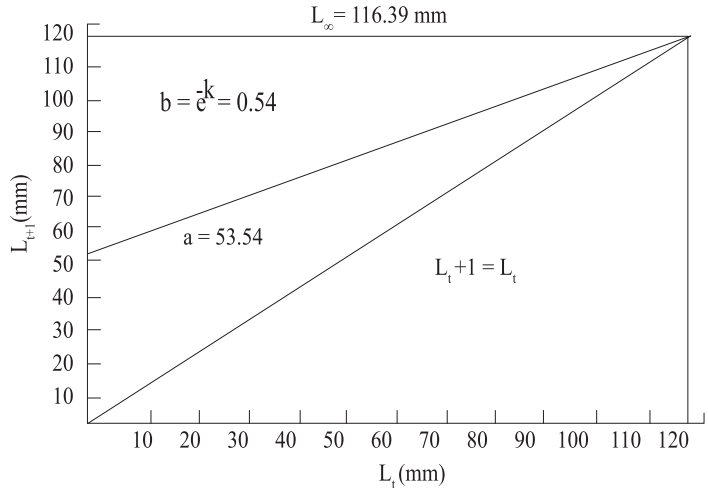

(b)

Fig. 2. Estimation of growth parameters by Ford-Walford plot for S. melantho. (a): Male, (b): Female

Growth in both sexes showed rapid increase in length in the initial months i.e., males attained a size of $62.69 \mathrm{~mm}$ in four months while females attained $82.45 \mathrm{~mm}$. Then onwards both males and females showed steady growth without much increase in size, with males attaining $96.75 \mathrm{~mm}$ and females reaching $111.72 \mathrm{~mm}$ at 12 months (Fig. 3).

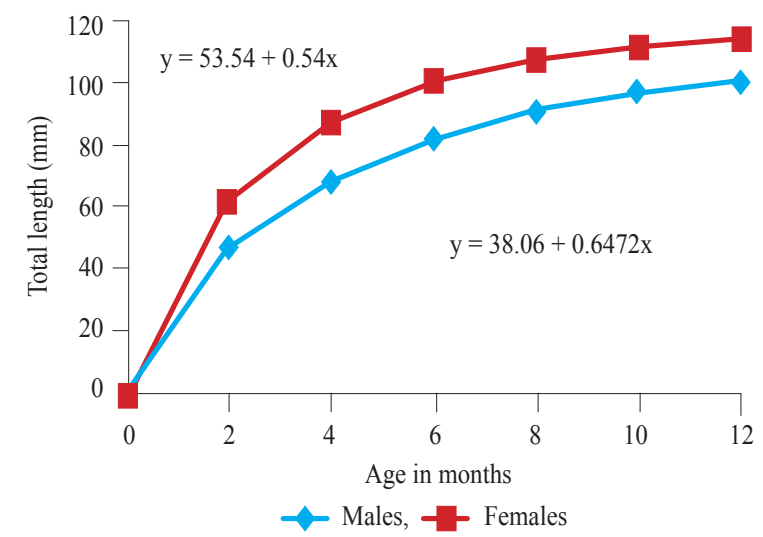

Fig. 3. Ford-Walford growth curves of males and females in S. melantho

Age at zero length

The age at zero length $\left(\mathrm{t}_{0}\right)$ was calculated by substituting the growth parameters, asymptotic length $\left(\mathrm{L}_{\infty}\right)$ and growth coefficient $(\mathrm{K})$ in von Bertalanffy growth equation and the $\mathrm{t}_{0}$ age was 1.61 in male and 1.62 in female per month and 0.13 and $0.13 \mathrm{y}^{-1}$ in male and female respectively (Fig. 4).

\section{von Bertalanffy growth equation}

The length of the shrimp at specific time (age) in both the sexes was obtained by substituting $\mathrm{L}_{\infty}, \mathrm{K}$ and $\mathrm{t}_{0}$ in the von Bertalanaffy growth equation:

Males : $\mathrm{L}_{\mathrm{t}}=107.88\left(1-\mathrm{e}^{-2.6016(\mathrm{t}-0.1344)}\right)$

Females : $\mathrm{L}_{\mathrm{t}}=116.39\left(1-\mathrm{e}^{-3.6972(\mathrm{t}-0.01346)}\right)$

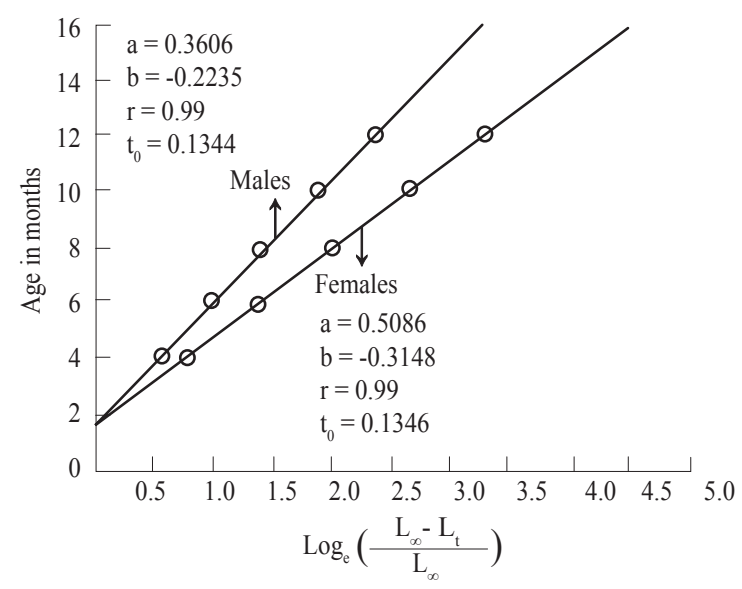

Fig. 4. Relationship between age in months and $\log _{e}\left(\frac{\mathrm{L}_{\alpha}-\mathrm{L}_{t}}{\mathrm{~L}_{\mathrm{w}}}\right)$ in males and females of $S$. melantho

Accordingly the length attained at 3, 6, 9 and 12 months of age were 29.01, 66.8, 92.65 and $96.75 \mathrm{~mm}$ for males and 41.71, 86.76, 109.12 and $111.72 \mathrm{~mm}$ in females respectively. Based on these values, growth curves for males and females were drawn (Fig. 5). The rate of growth in females was faster than males. The longevity of males and females was estimated as 3 years. It was found that males attained a total length of $96.75 \mathrm{~mm}$ at the end of first year and $107.06 \mathrm{~mm}$ at the end of second year. Similarly females attained a total length of $111.73 \mathrm{~mm}$ at the end of first year and $116.28 \mathrm{~mm}$ at the end of second year.

\section{ELEFAN I (FiSAT II software version 1.2.2)}

The $\mathrm{L}_{\infty}$ obtained by ELEFAN I for males was $106.1 \mathrm{~mm}$ and $\mathrm{K}=2.17 \mathrm{yr}^{-1}$ with highest $\mathrm{R}_{\mathrm{n}}$ value $(0.150)$. In case of females, $\mathrm{L}_{\infty}$ was $116.8 \mathrm{~mm}$ and $\mathrm{K}=2.10$ $\mathrm{yr}^{-1}$ with a highest $\mathrm{R}_{\mathrm{n}}$ value of 0.153 (Fig. $6 \mathrm{a}, \mathrm{b}$ ). $\mathrm{t}_{0}$ for males and females calculated by substituting $\mathrm{L}_{\infty}$ and $\mathrm{K}$ in Pauly's equation was -0.05 . These values were fitted in the von Bertalanffy growth equation. Males attained a 


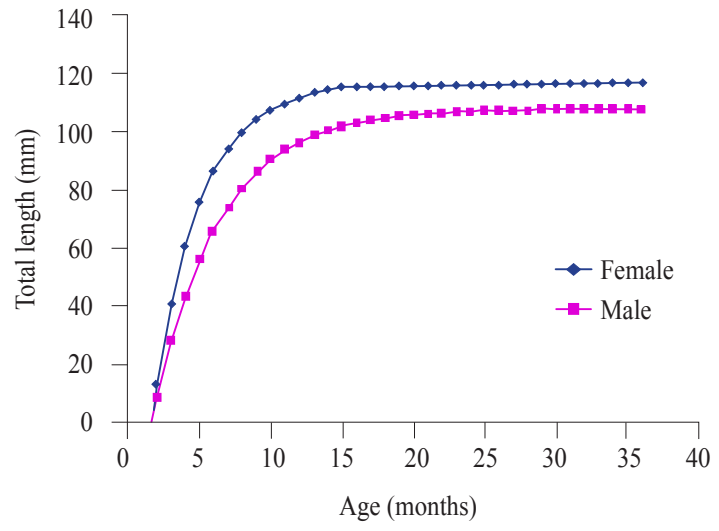

Fig. 5. von Bertalanffy growth curves of $S$. melantho

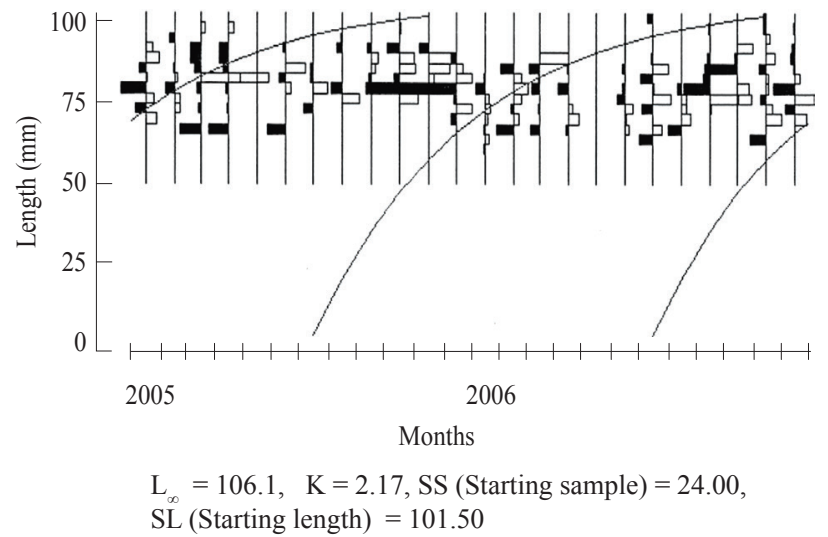

(a) in the subsequent months (Fig. 7). The percentage growth rate was more in females than males and was almost negligible after 22 months in both the sexes.

Age and growth in crustaceans is estimated by identifying the successive age groups of the populations from the modes of the length frequency distributions due to lack of well defined characteristics of age determination (Yano and Koboyashi, 1969). Cheung (1963) observed the growth of Solenocera subnuda as $6.49 \mathrm{~mm}$ in males and $6.96 \mathrm{~mm}$ in females per month and it was found to be the same in S. indica (Kunju, 1968). A life span of 16-20 months with an average monthly growth rate of $3.80 \mathrm{~mm}$ for males and $5.20 \mathrm{~mm}$

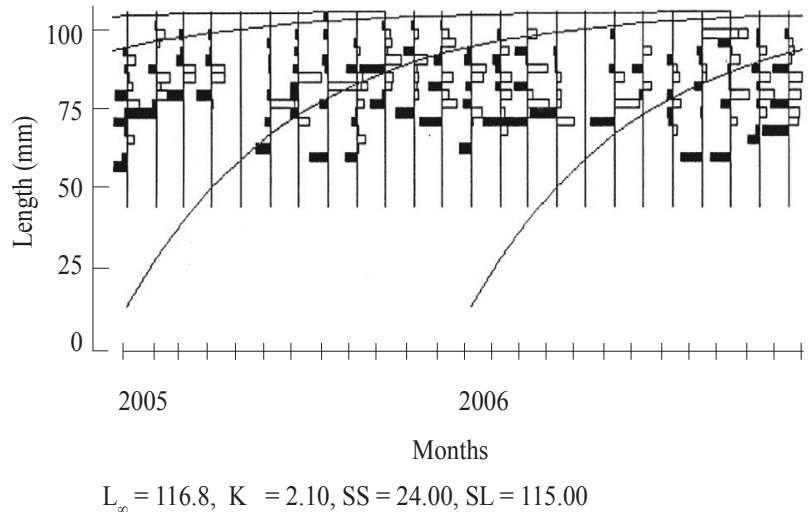

(b)

Fig. 6. Estimate of $\mathrm{L}_{\infty}$ and $\mathrm{K}$ of $S$. melantho using ELEFAN I. (a): Male, (b): Female

total length of $95.24 \mathrm{~mm}$ during first year and $104.86 \mathrm{~mm}$ during second year while in females it was $103.92 \mathrm{~mm}$ in first year and $115.22 \mathrm{~mm}$ in the second year. The method confirmed the longevity of $S$. melantho as 36 months.

\section{Growth performance index ( $\left.\varphi^{\prime}\right)$}

Growth performance index was 4.48 for males and 4.69 for females based on the parameters from modal progression method and that of ELEFAN I the values were 4.38 and 4.45 for males and females respectively. A comparison of $\mathrm{L}_{\infty}, \mathrm{K}, \mathrm{t}_{0}$ and $\varphi$ ' from both the methods are given in Table 1.

\section{Growth rate}

The percentage of growth rate of both males and females in the initial months was high which decreased for females was reported in Solenocera crassicornis by Sukumaran (1978). Demestre and Abello (1993) noticed maximum asymptotic length in females of Solenocera membranacea in the North-western Mediterranean Sea. Baelde (1994) analysed monthly length-frequency distribution of deepwater royal red shrimp, Haliporoides sibogoe using MULTIFAN method (Fournier et al., 1991) and found that females grew faster and attained larger sizes than males. Ohtomi and Irieda (1997) noticed faster growth rate in females than males and recorded the longevity of both males and females of S. melantho as 37 months in Kagoshima Bay, Southern Japan.

Oh et al. (2005) reported higher values for growth parameters in female $S$. melatho from Korean waters

Table 1. Growth parameters, indices and size attained in $S$. melantho estimated by modal progression and ELEFAN I

\begin{tabular}{lllllllll}
\hline Method & Sex & $\mathrm{L}_{\infty}$ & $\mathrm{K} \mathrm{y}^{-1}$ & $\mathrm{t}_{0}$ & $\mathrm{R}_{\mathrm{n}}$ & $\varphi^{\prime}$ & Size I year (mm) & Size II year $(\mathrm{mm})$ \\
\hline Modal progression analysis & Male & 107.8 & 2.61 & 0.13 & - & 4.4825 & 96.75 & 107.06 \\
& Female & 116.3 & 3.96 & 0.13 & - & 4.6997 & 111.73 & 116.28 \\
\hline ELEFAN I & Male & 106.1 & 2.17 & -0.05 & 0.150 & 4.3879 & 95.24 & 104.86 \\
& Female & 116.8 & 2.10 & -0.05 & 0.153 & 4.4571 & 103.92 & 115.22 \\
\hline
\end{tabular}




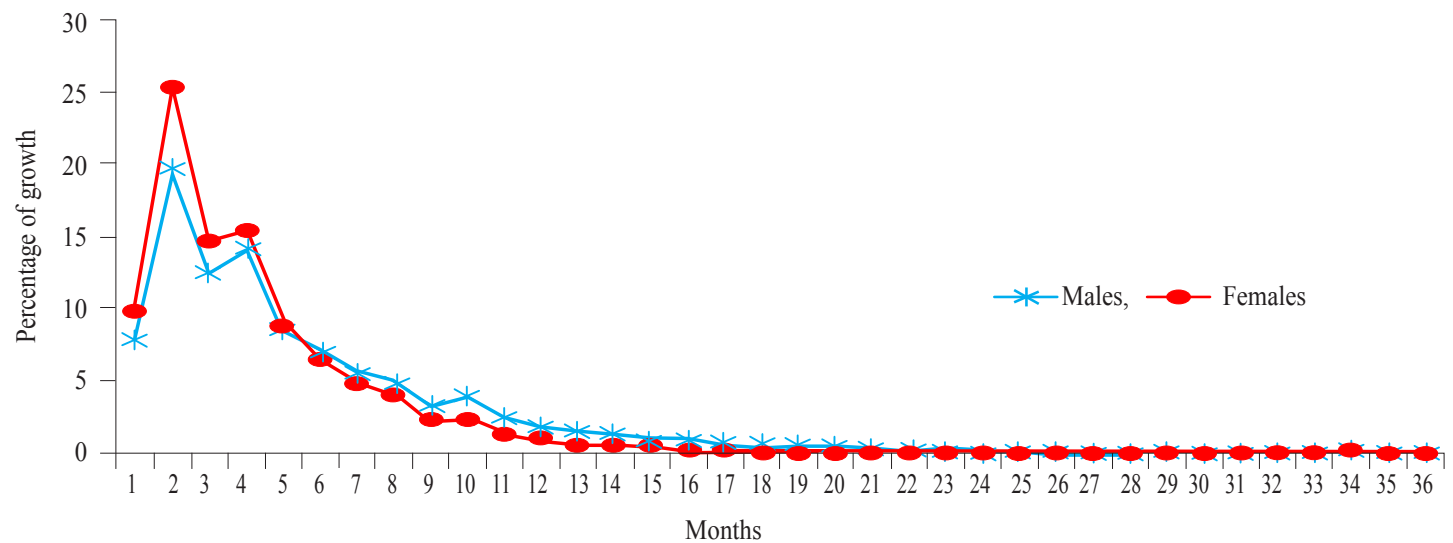

Fig. 7. Percentage growth rate per month in males and females of S. melantho

than males with performance indices $\left(\varphi^{\prime}\right)$ of 3.29 and 3.15 for females and males respectively. Dineshbabu and Manissery (2007) observed the life span of ridge back shrimp $S$. choprai as 30 months with the males attaining $66 \mathrm{~mm}$ at the end of 12 months; $88 \mathrm{~mm}$ at the end of 24 months and females attaining $83 \mathrm{~mm}$ in 12 months and $109 \mathrm{~mm}$ at the end of 24 months. According to them growth performance index $(\varphi)$ and the growth parameters $\left(\mathrm{L}_{\infty}\right.$ and $\left.\mathrm{K}\right)$ in males and females were $1.22 ; 99 \mathrm{~mm} ; 1.1 \mathrm{y}^{-1}$ and $1.49 ; 120 \mathrm{~mm} ; 1.18 \mathrm{y}^{-1}$ respectively. In the East China Sea, Li et al. (2012) estimated the growth parameters of $S$. melantho using the modified von Bertalanffy growth equations as: $\mathrm{L}_{\infty}=46.75 \mathrm{~mm} \mathrm{CL}, \mathrm{K}=1.14 / \mathrm{y}^{-1}, \varphi^{\prime}=3.115$ for males and $\mathrm{L}_{\infty}=33.6 \mathrm{~mm} \mathrm{CL}, \mathrm{K}=1.26 / \mathrm{y}^{-1}, \varphi^{\prime}=3.28$ for females. According to them the life span of females is 2.43 years and 2.20 years for males.

In the present study the growth parameters estimated for $S$. melantho are: $\mathrm{L}_{\infty}=107.9 \mathrm{~mm}, \mathrm{~K}=2.6106$, $\mathrm{t}_{0}=0.1344, \varphi^{\prime}=4.4825$ for males and for females $\mathrm{L}_{\infty}=116.4 \mathrm{~mm}, \mathrm{~K}=3.6972 \mathrm{y}^{-1}, \mathrm{t}_{0}=0.1346, \varphi^{\prime}=4.6997$. By ELEFAN I (FiSAT), the growth parameters obtained for males are $\mathrm{L}_{\infty}=106.1 \mathrm{~mm}, \mathrm{~K}=2.17 \mathrm{y}^{-1}, \mathrm{t}_{0}=-0.05$, $\varphi^{\prime}=4.3879$ and for females $\mathrm{L}_{\infty}=116.8 \mathrm{~mm}, \mathrm{~K}=2.1 \mathrm{y}^{-1}$, $\mathrm{t}_{0}=-0.05, \varphi^{\prime}=4.4571$. The longevity of both males and females of $S$. melantho has been estimated as 36 months by both the methods, whereas Ohtomi and Iridea (1997) have reported the longevity of $S$. melantho to be around 37 months in Kagoshima Bay of Southern Japan. Li et al. (2012) found the maximum life span of $S$. melantho to be 2.43 years for females and 2.20 years for males in the East China Sea. Females grow faster than males, growth being rapid in initial months i.e., $62.69 \mathrm{~mm}$ in males and $82.45 \mathrm{~mm}$ in females for four months and then onwards both males and females showed steady growth without much increase in size.

\section{Acknowledgements}

The authors are grateful to the Head, Department of Marine Living Resources, Andhra University, Visakhapatnam for providing facilities to carry out the work.

\section{References}

Baelde, P. 1994. Growth, mortality and yield per recruit of deep-water royal red prawns (Haliporoides sibogae) off Eastern Australia, using the length- based MULTIFAN method. Mar. Biol., 118: 617-625.

Cheung, T. S. 1963. The natural history of the commercial species of Hong-Kong Penaeidae (Crustacea, Decapoda). Ann. Mag. Nat. Hist., 6(13): 401-433.

Demestre, M. and Pere Abello 1993. Growth and distribution of Solenocera membranacea (Risso, 1816) (Decapoda, Dendrobranchiata) in the North-western Mediterranean Sea. Sci. Mar., 57(2 - 3): 161-166.

Dineshbabu, A. P. and Joseph, K. Manissery 2007. Morphometric relationship and growth of the 'ridge back shrimp Solenocera choprai (Decapoda: Crustacea) from Mangalore (South-west Coast of India). Indian J. Mar. Sci., 36(1): 65-70.

Ford, E. 1933. An account of the herring investigations conducted at Plymoth during the years from 1924-1933. J. Mar. Biol. Ass. N. S., 19: 305-384.

Fournier, D. A., Sibert, J. R. and Terceiro, M. 1991. Analysis of length frequency samples with relative abundance data for the Gulf of Marine Northern shrimp (Pandalus borealis) by the MULTIFAN method. Canadian J. Fish Aquat. Sci., 48: 591-598.

Froglia, C. and Gramitto, M. E. 1987. Notes on growth and biology of Solenocera membranacea (Risso, 1816) in the Central Adriatic Sea (Decaoida: Solenoceridae). In: Sarda, F. (Ed.), Third Colloquium. Mediterranean Crustacea Decapoda. Barcelona, Invest. Pesq. (Barc.), 51(1): 189-199. 
Garcia, S. and Le Reste, L. 1981. Life cycles, dynamics, exploitation and management of coastal penaeid shrimp stocks. FAO Fisheries Technical paper, 203: 1-25.

Gulland, J. A. 1969. Manual of methods for fish stock assessment. Part. I. Fish population analysis. FAO Marine Fisheries Sciences, 4: 154.

Hall, D. N. F. 1962. Observations on the taxonomy and biology of some Indo-West Pacific Penaeidae (Crustacea, Decapoda). Fish. Publ. Colon. Off. Lond., 17: 1-229.

Kunju, M. M. 1968. Some aspects of biology of Solenocera indica Nataraj. FAO Fisheries Report, 57: 467-486.

Li, Hui Yu, Cheng, Jia Huai and Li, Sheng Fa 2012. Reproductive biology and growth of the deep-water shrimp Solenocera melantho in the East China Sea. J. Shell Fish Res., 31(3): 841-846.

Maheswarudu, G., Sampson Manickam, P. K., Vedavyasa Rao, P., Arputharaj, M. R. and Muniyandi, K. 1994. Some aspects of biology and exploitation of the green tiger prawn, Penaeus (Penaeus) semisulcatus De Haan from Mandapam (Palk Bay) and Pamban (Gulf of Mannar), south-east coast of India. Indian J. Fish., 41(2): 55-64.

Maheswarudu, G., Sudhakar Rao, G., Rajamani, M., Thangaraj Subramanian, V., Manmadhan Nair, K. R., Saleela, K. N., Dhanwanthari, E., Miriam Paul and Unnithan, A. K. 2014. Penaeid prawn resources along the east coast of India during 1991-2011. Mar. Fish. Infor. Serv, $T \&$ E Ser., 219: 8-14.

Maheswarudu, G., Miriam Paul Sreeram, Dhanwanthari, E., Varma, J. B., Sajeev, C. K. and Satya Rao, S. 2015. Exploitation of penaeid shrimp resources by small mechanised trawlers off Visakhapatnam, Andhra Pradesh. Indian J. Fish., 62(2): 7-13.

Niamaimandi, N., Aziz Bin Arshand, Siti Khalizah Dand, Ross Cheroos Saed and Bahram Kiabi 2007. Population dynamics of green tiger prawn, Penaeus semisulcatus (De Haan) in Bushehr coastal waters, Persian Gulf. Fish. Res., 86: 105-112.
Oh, T. Y., Choi, J. H., Cha, H. K. and Kim, J. I. 2005. Growth and reproduction of deep water mud shrimp (Solenocera melantho) around Geomun Island Korea. J. Korean Fish. Soc., 38: 223-238 (In Korean).

Ohtomi, J. and Irieda Shinya 1997. Growth of the deep water mud shrimp, Solenocera melantho De Man, 1907 (Decapoda, Penaeoidea, Solenoceridae) in Kagoshima Bay, Southern Japan. Crustaceana, 70: 45-58.

Pauly, D. 1979. Gill size and temperature as governing factors in fish growth: a generalisation of von Bertalanffy's growth formula. Berichte des Instituts fur Meereskunde on der. Univ. Kiel., 63: XV + 156 pp.

Pauly, D. 1983. Some simple methods for the assessment of tropical fish stocks. FAO Fish. Tech. Pap., 234: 52.

Pauly, D. and Munro, J. L. 1984. Once more on growth comparison of fish and invertebrates. Fish Byte, 2(2): 21.

Pauly, D. and David, N. 1981. ELEFAN I, a basic program for the objective extraction of growth parameters from length-frequency data. Meeresforschung, 28(4): 205-211.

Rao, G. S. and Krishnamoorthi, B. 1990. Age and growth of Metapenaeus monoceros (Fabricius) along the Kakinada coast. J. Mar. Biol. Ass. India, 32 (1\&2): 154-161.

Sparre, P. and Venema, S. C. 1992. Introduction to tropical fish stock assessment, Part-I Manual. FAO Press, Rome, $376 \mathrm{pp}$.

Sukumaran, K. K. 1978. Studies on the fishery and biology of Solenocera crassicornis (H. Milne Edwards) from Bombay waters. J. Mar. Biol. Ass. India, 20 (1\& 2): 32-40.

von Betalanffy, L. 1938. A quantitative theory of organic growth Hum. Biol., 10(2): 181-213.

Walford, L. A. 1946. A new graphic method of describing the growth of animals. Biol. Bull., 90(2): 141-147.

Yano, J. and Kobayashi, S. 1969. Classification and age determination in crustacean. Bull. Japan. Soc. Sci. Fish., 35(1): 34-40. 